\title{
INFLUENZA A VIRUS INFECTION IN DOGS: EPIZOOTIOLOGY, EVOLUTION AND PREVENTION - A REVIEW
}

\author{
Xing XIE, Ke MA and Yongjie LIU* \\ College of Veterinary Medicine, Nanjing Agricultural University, Nanjing, 210095, China
}

(Received 28 August 2015; accepted 28 October 2015)

\begin{abstract}
Canine influenza virus (CIV) is an enveloped virus belonging to the genus Influenza virus $A$ within the family Orthomyxoviridae. Prior to 2004, only sporadic outbreaks of canine influenza had been observed in dog populations around the world. However, in 2004 an H3N8 influenza virus of equine origin caused severe respiratory disease in racing greyhounds in Florida; subsequently, cases of dogs affected with various subtypes of CIV have been reported in many countries. Here, we performed a structured review of CIV, including its emergence, evolution and epizootiology. Although CIV causes a disease of low mortality, the potential public health threat it poses due to close contact between dogs and humans highlights the necessity of promoting surveillance for this virus.
\end{abstract}

Key words: Canine influenza virus, epizootiology, origin, virulence

Within the family of Orthomyxoviridae, the genus Influenza virus A includes enveloped viruses, of 80 to $120 \mathrm{~nm}$ in diameter, with negative-sense single-stranded RNA genome. The genome consists of eight segments encoding 10 proteins: haemagglutinin (HA), neuraminidase (NA), polymerase subunits (PA, PB1 and PB2), nucleoprotein (NP), interferon antagonist (NS1), nuclear export protein (NEP, formerly called NS2), matrix protein (M1), and channel protein (M2) (Neumann et al., 2009). Of these proteins, HA and NA are the two major types of surface glycoproteins; the HA protein spikes limit the host range of influenza virus and determine its virulence, while the NA protein facilitates viral release from infected cells (Bao et al., 2008). Based on the antigenicity of the HA and NA protein molecules, the current influenza A viruses are classified into 17 HA subtypes (H1-H17) and 9 NA subtypes (N1-N9) (Tong et al., 2012). Serologically identical viruses (i.e. having the same $\mathrm{H}$ and $\mathrm{N}$ subtype numbers) might have considerable differences in their other genome segments that contribute significantly to the determination of host specificity and pathogenicity. Since most of the genome fragments seem to be capable of reassorting, every member of the genus represents a single species named Influenza A virus (IAV).

\footnotetext{
“Corresponding author; E-mail: liuyongjie@njau.edu.cn; Phone/Fax: 0086 (025) 843-98606
} 


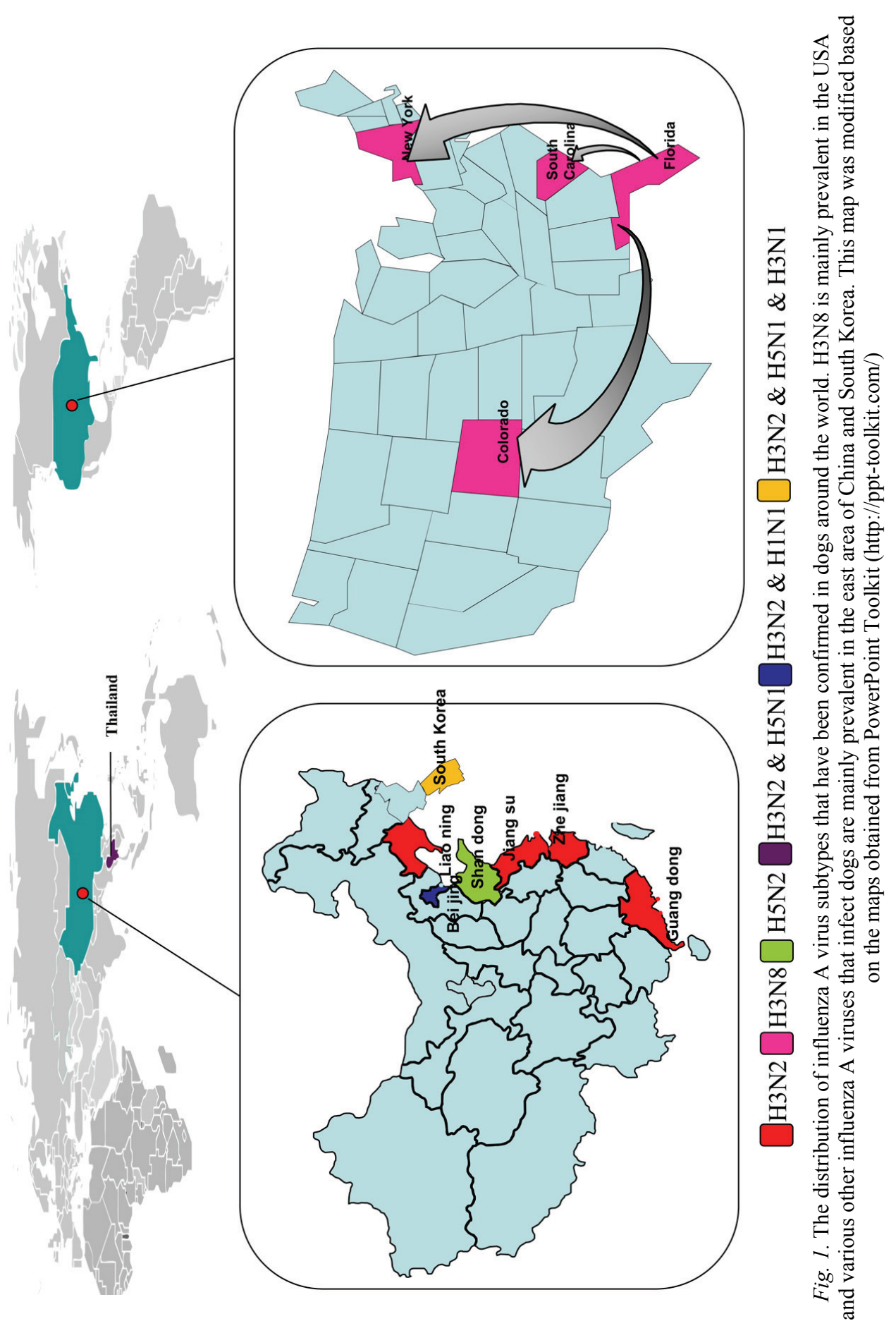

Acta Veterinaria Hungarica 64, 2016 
The natural hosts of IAVs are birds but certain IAV lineages may infect different additional hosts, most frequently humans, swine, and horse. IAV may also infect other species of poultry or mammals in addition to the major hosts; however, these infections do not lead to sustained viral transmission or establish permanent lineages within these new hosts (Lipatov et al., 2004). In the 1970s, human H3N2 influenza viruses were reported to infect dogs (Romváry and Tanyi, 1975; Romváry et al., 1975). Nevertheless, the dog was not considered a reservoir species for influenza virus, because most infected dogs did not exhibit obvious clinical signs, and there was also no evidence that the virus could continuously spread among dogs. However, in 2004, an H3N8 influenza virus of equine origin caused an extensive epizootic of respiratory disease in dogs in Florida (Crawford et al., 2005). Subsequently, in 2007, transmission of an H3N2 avian influenza virus (AIV) to dogs was reported in South Korea (Song et al., 2008). By now, cases of dogs infected with various subtypes of IAV have been reported in many other countries and regions (see Fig. 1). It is noteworthy that a recent observation of an H3N2 subtype of human-canine influenza virus reassortant in dogs poses a risk to human health, which emphasises the necessity of promoting surveillance for CIV (Parrish et al., 2015). Dogs are the most intimate companions of humans, and the close contact between humans and dogs increases the possibility that dogs could transmit the virus to humans as intermediate hosts.

\section{Subtype diversity of IAV in dogs}

At present, there are at least six influenza virus subtypes that have been reported to infect dogs: H3N8, H3N2, H5N1, H5N2, H3N1 and H1N1 (see Table 1). It has been confirmed that the $\mathrm{H} 3 \mathrm{~N} 8$ and $\mathrm{H} 3 \mathrm{~N} 2$ viruses can cause sustained transmission between dogs. Although other subtypes can also infect dogs, there is no sufficient evidence to show that these subtypes can be transmitted continuously in dog populations.

H3N8 subtype. Crawford et al. (2005) reported an outbreak of severe respiratory disease in racing greyhounds at a Florida racetrack. Subsequently, a strain of IAV was isolated, and molecular analyses indicated that the eight genes of this virus shared $96 \%$ sequence identity with equine influenza virus (EIV) H3N8. However, the canine isolates formed a distinct monophyletic group separated from the ancestral equine lineage (Payungporn et al., 2008), and were therefore named 'canine influenza subtype H3N8 virus'. The virus has since been recognised in at least 38 states of the USA, and has spread to the northeastern and western regions of the USA (Dubovi, 2010; Rivailler et al., 2010).

Anderson et al. (2012) tested serum samples from greyhounds and shelter dogs for the presence of antibodies to the $\mathrm{H} 3$ protein. All samples from greyhounds taken between 1999 and 2004 were seropositive; however, among all of 
the samples from shelter dogs, only one contained detectable anti-H3 antibodies. Payungporn et al. (2008) isolated CIV H3N8 from non-greyhound dogs, indicating that this virus could infect canine breeds other than greyhounds. To further analyse the genetic evolution of H3N8 CIV, Pecoraro et al. (2013) collected over 5100 nasal swabs from shelter dogs in Colorado, New York, and South Carolina. Nineteen viruses were isolated, and their HA genes were sequenced. The phylogenetic analysis indicated that H3N8 CIV might be diverging into two lineages: Colorado and New York, which are closely related to the equine cluster (see Fig. 2). Whether these antigenic variations have provided CIV the ability to evade the immune response is still unknown.

Table 1

Subtypes of influenza viruses that have been confirmed to infect dogs

\begin{tabular}{lccccc}
\hline Influenza virus & $\begin{array}{c}\text { Time of } \\
\text { occurrence }\end{array}$ & $\begin{array}{c}\text { Place of } \\
\text { occurrence }\end{array}$ & $\begin{array}{c}\text { Continuous } \\
\text { spread }\end{array}$ & $\begin{array}{c}\text { Susceptible } \\
\text { host }\end{array}$ & References \\
\hline $\begin{array}{l}\text { H3N8 } \\
\text { (equine origin) }\end{array}$ & 2004 & USA & Yes & equine, canine & Crawford et al. (2005) \\
HPAI H5N1 & 2004 & Thailand & No & $\begin{array}{l}\text { human, poultry, } \\
\text { canine }\end{array}$ & Songserm et al. (2006) \\
$\begin{array}{l}\text { H3N2 } \\
\text { (avian origin) }\end{array}$ & 2007 & South Korea & Yes & $\begin{array}{l}\text { human, poultry, } \\
\text { canine, feline }\end{array}$ & Song et al. (2008) \\
$\begin{array}{l}\text { H1N1 } \\
\text { (swine origin) }\end{array}$ & 2009 & China & No & $\begin{array}{l}\text { human, porcine, } \\
\text { feline, canine }\end{array}$ & Lin et al. (2012a) \\
H5N2 & 2009 & China & No & poultry, canine & Zhan et al. (2012) \\
H3N1 & 2010 & South Korea & No & canine & Song et al. (2012) \\
\hline
\end{tabular}

Since dogs infected with H3N8 viruses of equine origin were discovered in the USA, similar interspecies transmissions have also been reported in other countries. In the UK, a serological investigation conducted by Newton et al. (2006) suggested that EIV H3N8 was transmitted from horses to English foxhounds. A retrospective study by Daly et al. (2008) also revealed that EIV H3N8 caused a respiratory disease outbreak among English foxhounds. During the epidemic of H3N8 EIV in Australia, a large number of dogs developed influenza-like disease after being in contact with affected horses (Kirkland et al., 2010). Schulz et al. (2014) investigated the prevalence of CIV H3N8 in dogs in Germany, and concluded that the incidence of CIV H3N8 infection in dogs was low in that country. The epizootiological data indicate that canine influenza caused by the H3N8 virus became endemic in the USA only (Gibbs and Anderson, 2010). 


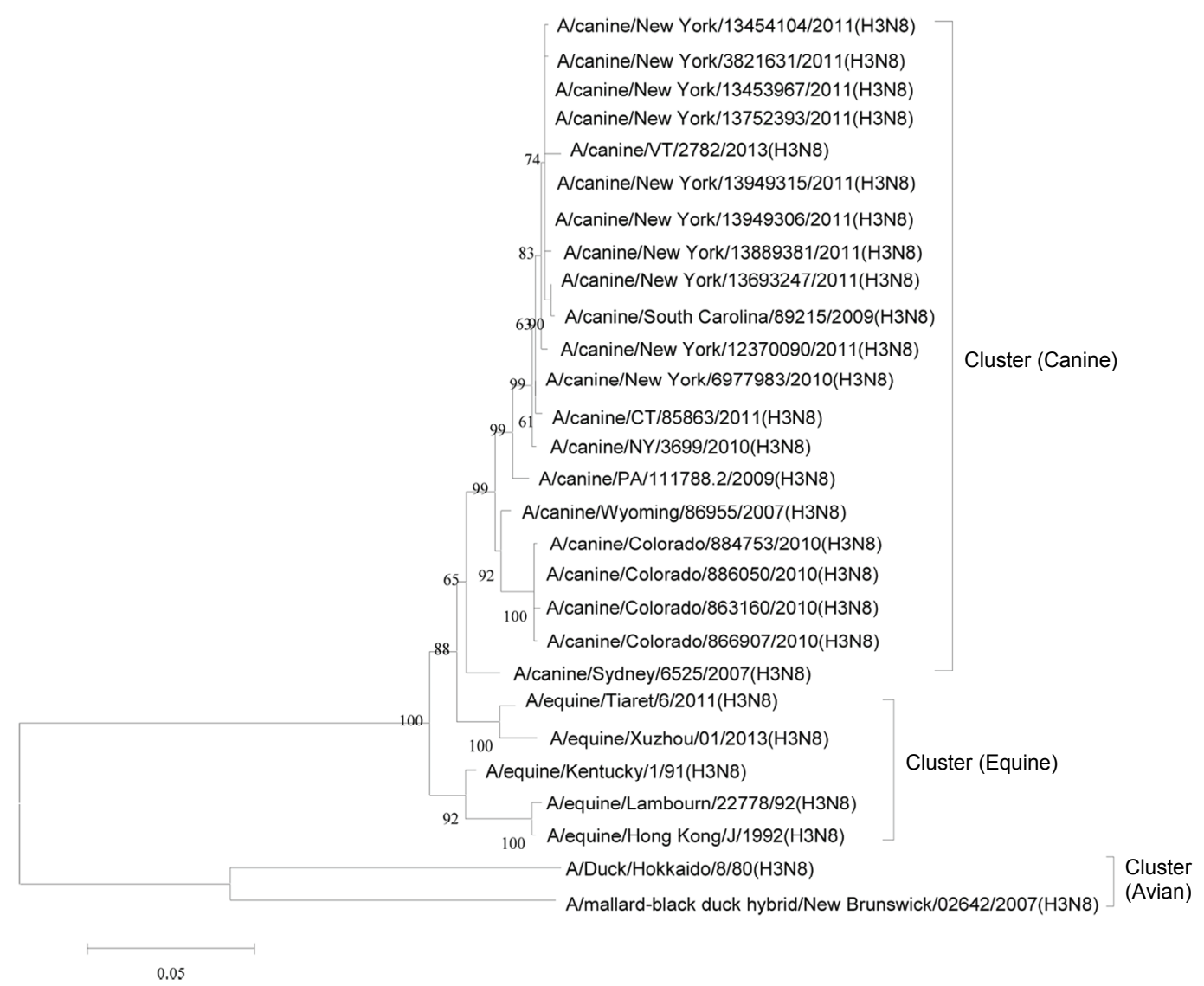

Fig. 2. Phylogenetic tree of H3N8 influenza A viruses, based on the HA gene sequences, obtained using the neighbour-joining method and bootstrap test (1000 replicates). The evolutionary distances were computed using the maximum composite likelihood method. The phylogenetic tree was generated using MEGA5.1 software. The tree contains HA genes of representative isolates from dogs, horses and ducks

H3N2 subtype. H3N2 canine influenza virus was first reported in South Korea (Song et al., 2008). Sequencing results indicated that all eight gene segments of the isolate displayed identity to H3N2 avian influenza virus (AIV), which was between $95.5 \%$ and $98.8 \%$. After experimental infection of Beagles, nasal discharge, cough and low-grade fever were observed clinically. At autopsy, histopathological lesions in the lungs were detected (Song et al., 2008). A further study demonstrated that all the experimentally infected and contact-exposed dogs showed elevated rectal temperatures, virus shedding, seroconversion, and severe necrotising tracheobronchitis and bronchioalveolitis. Minor differences among infected dogs in the severity of tracheitis, bronchitis and other lesions were observed by histological examination (Piccirillo et al., 2010). 


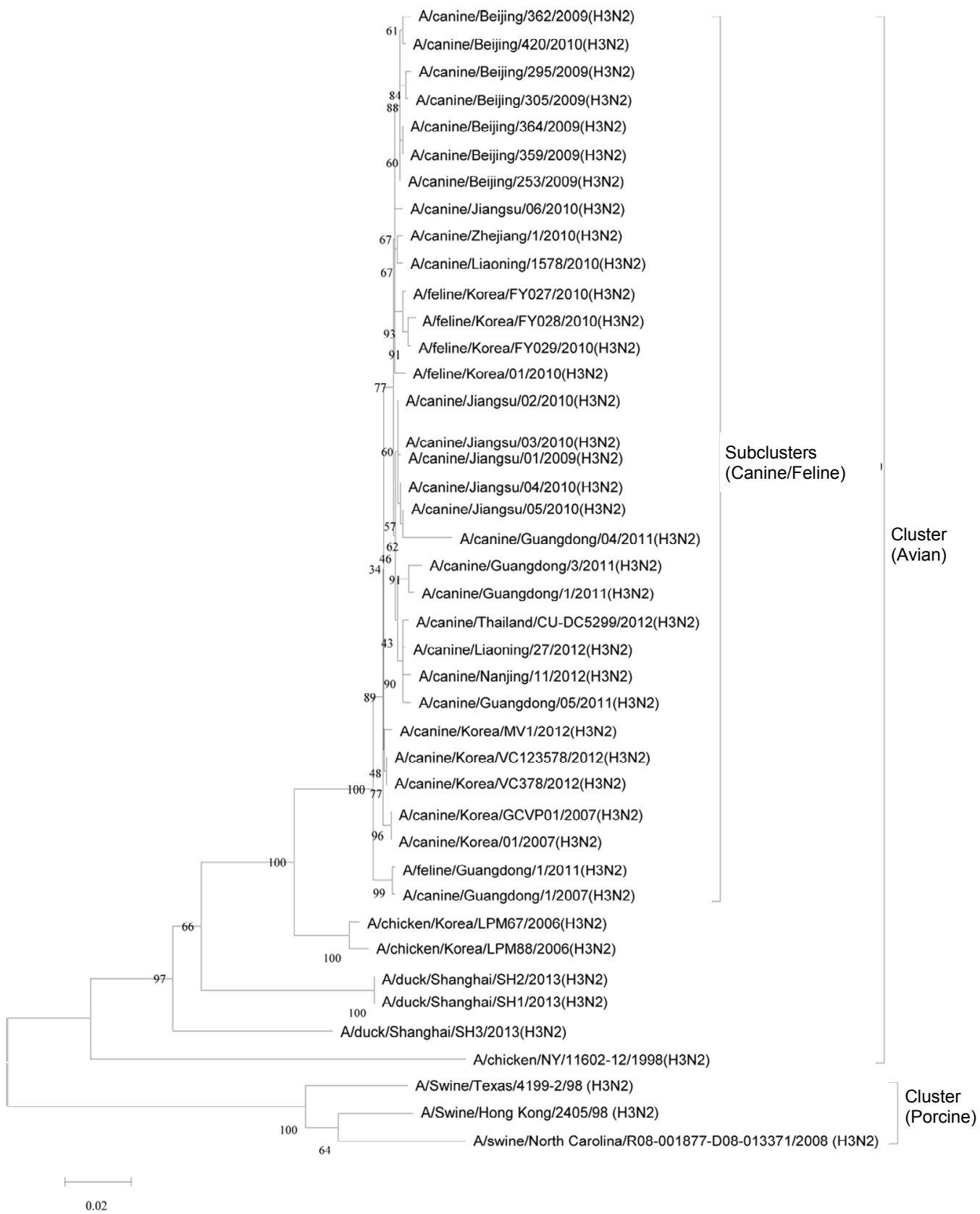

Fig. 3. Phylogenetic tree of H3N2 influenza A viruses, based on the HA gene sequences, obtained using the neighbour-joining method and bootstrap test (1000 replicates). The evolutionary distances were computed using the maximum composite likelihood method. The phylogenetic tree was generated using MEGA5.1 software. The tree contains HA genes from representative isolates from dogs, swine, birds and cats 
To clarify the emergence of CIV H3N2 infection in dogs, Lee et al. (2012) launched a retrospective survey, which tested 980 serum samples collected between 2004 and 2007 and indicated that this virus had already been circulating in dogs in 2005. Canine cases of H3N2 virus infection have been reported frequently. Song et al. (2011) isolated a virus from the lung tissue of a cat. Eight genome segments of this feline isolate shared $99.0-99.8 \%$ sequence identity with the H3N2 CIV. In order to better understand the homology between influenza viruses of feline, canine, avian and swine origin, we compared the HA sequence of 42 different strains of H3N2 influenza viruses, and the phylogenetic analyses indicated that feline-derived influenza viruses are most closely related to canine influenza viruses, and both are included in the avian lineage cluster (see Fig. 3). Jeoung et al. (2013) reported a 2010 canine influenza outbreak among pet dogs kept in an animal shelter in South Korea, and 28 cats in the same shelter also exhibited signs of typical respiratory diseases. These studies demonstrate that cats are also susceptible to CIV H3N2, suggesting that canines may act as intermediate hosts and spread CIV H3N2 to other species.

Cases of CIV H3N2 infection have also been reported in China. Li et al. (2010) isolated four strains of CIV H3N2 from dogs with severe respiratory disease in Guangdong Province, and found that these four strains were most closely related to the Korean H3N2 virus isolated in 2007. Subsequently, six strains of CIV H3N2 were isolated in Jiangsu Province, and their pathogenicity has been characterised both in mice (Lin et al., 2012b) and dogs (Zeng et al., 2013). Molecular analysis indicated that all eight genes of the six strains shared high (>99\%) sequence identity with the CIV H3N2 isolates from cats in South Korea (Lin et al., 2012b). The same subtype has also been reported by other researchers (Sun et al., 2013; Teng et al., 2013). In a recent serological survey of CIV H3N2, 31 out of 882 serum samples (3.5\%) were positive for H3N2 virus, and positive samples were found every month between January 2012 and June 2013 (Sun et al., 2014).

In 2012, several clinical cases of influenza-like illness in dogs were noticed in a small animal hospital from Thailand. An avian-like H3N2 influenza virus was isolated from dogs, making it a signal event for those countries in Southeast Asia (Bunpapong et al., 2014).

H5N1 subtype. H5N1 highly pathogenic avian influenza (HPAI) is a highly contagious and deadly virus that occurs mainly in birds. Songserm et al. (2006) first isolated the H5N1 virus from a dog, and speculated that the virus may have been transmitted from infected ducks to dogs. In Thailand, a serological investigation in 2005 revealed that 160 out of 629 dogs were positive for antibodies to H5N1 influenza virus, suggesting that dogs could act as a reservoir for H5N1 virus (Butler, 2006). Reports concerning the susceptibility of dogs to H5N1 virus are controversial. In a study from Maas et al. (2007), three Beagles were inoculated with H5N1 AIV and the inoculated dogs did not exhibit signifi- 
cant changes in body temperature or clinical signs. Similar results were also obtained in the study by Giese et al. (2008). In contrast, the experiments of Chen et al. (2010) showed that Beagles inoculated with H5N1 AIV presented significant clinical signs of influenza. The contrasting results may be due to the fact that the pathogenicity of $\mathrm{H} 5 \mathrm{~N} 1$ influenza virus for dogs might correlate with the viral strains.

H1N1 subtype. Since the human H1N1 influenza outbreak in Mexico and the USA in 2009, pandemic H1N1 influenza has erupted all over the world, and many cases of H1N1 infection have been reported among non-human species as well, such as cats (Sponseller et al., 2010) and pigs (Han et al., 2012). Lin et al. (2012a) reported the isolation of an H1N1 virus from dogs with clinical signs, and all eight gene segments of this isolate were closely related to the H1N1/2009 influenza virus circulating in humans, suggesting that the H1N1/2009 virus was directly transmitted to dogs from humans without reassortment. To determine the prevalence of H1N1/2009 in dogs in Italy, Dundon et al. (2010) analysed 964 serum specimens and 7 were demonstrated to be positive for antibodies to H1N1 virus. These results suggested that the virus detected in dogs might have been transmitted from H1N1/2009-infected owners via direct contact. Whether dogs are susceptible to the H1N1/2009 influenza virus is still uncertain. More experimental data are also needed to demonstrate whether H1N1/2009 can lead to sustained transmission in dogs.

H5N2 subtype. Cases of mammals infected with $\mathrm{H} 5 \mathrm{~N} 2$ have rarely been reported (Lee et al., 2009). However, a serological investigation from Zhan et al. (2012) indicated that out of 187 serum samples from dogs in Shandong Province, China, 6 were positive for $\mathrm{H} 5 \mathrm{~N} 2$ antibodies. An H5N2 isolate was obtained from the nasal swabs of an infected dog. Further study showed the viruses were shed through nasal discharge and could circulate from sick dogs to healthy ones and cause infection (Song et al., 2013). Also, Feng et al. (2014) conducted a contact exposure experiment in chickens and cats, demonstrating that H5N2 influenza virus could be directly transmitted from dogs to both of these animal species.

H3N1 subtype. During a recent epizootiological investigation on CIV in Korea, Song et al. (2012) isolated a novel subtype, H3N1. The HA gene nucleotide sequence of this isolate shared $96 \%$ identity with that of CIV H3N2 isolated in Korea and China, and the other 7 gene segments were highly similar (99.1$99.9 \%$ ) to $\mathrm{H} 1 \mathrm{~N} 1 / 2009$. Molecular investigation indicated that this isolate might be a natural reassortant of CIV H3N2 and H1N1/2009. Although there are no other reports of $\mathrm{H} 3 \mathrm{~N} 1$ in dogs, current evidence indicates that the reassortant $\mathrm{H} 3 \mathrm{~N} 1$ influenza virus has the ability to adapt to dogs, which highlights the need for strengthening monitoring systems for $\mathrm{H} 3 \mathrm{~N} 1$ in dogs. 


\section{Cross-species transfer of IAV}

Previous studies have demonstrated that influenza viruses preferentially bind to sialic acid attached to the penultimate sugar via a $(2,6)$-linked (SA $\alpha-2,6-$ Gal) and a (2,3)-linked (SA $\alpha-2,3-G a l)$ (Songserm et al., 2006). However, the H3N8 and H3N2 canine influenza viruses only recognise SA $\alpha-2,3-\mathrm{Gal}$, which mainly exists on the surface of epithelial cells in the bronchus and capillary bronchus and occurs at a lower concentration on the epithelial cells of the nasal mucosa, trachea and on type II pneumocytes (Jung et al., 2010; Muranaka et al., 2012). Pathological alterations found in dogs infected by influenza virus include necrosis and exfoliation of the tracheal and bronchial mucosa and the presence of a large number of lymphocytes and serous effusion in the alveolar spaces (Castleman et al., 2010). All of these findings are consistent with the distribution of the SA $\alpha-2,3-\mathrm{Gal}$ receptor in the canine respiratory tract. However, a recent study has indicated that sialic acid may not be the primary receptor for CIV. Lyoo et al. (2015) experimentally inoculated animals of several host species with CIV $\mathrm{H} 3 \mathrm{~N} 2$, and found that this virus was not sustainably replicating in the epithelial cells of the upper or lower respiratory tracts of mice, pigs, or chickens, in which SA $\alpha-2,3-G a l$ dominates. This result may suggest that the pathogenicity is linked to preferential binding between the influenza viruses and sialic acid in animals.

To better understand the evolution of CIV from equine to canine crossspecies transfer, Collins et al. (2014) analysed and compared the structures of the HA proteins from equine and canine H3N8 influenza viruses using X-ray crystallography. One change in the receptor binding site, the amino acid substitution HA1 Trp-222 to Leu, distinguishes canine HAs from equine HAs. The same mutation was also detected in canine H3N2 viruses isolated in South Korea and southern China in 2005 from their proposed avian HA precursor (Li et al., 2010). Interestingly, in addition to CIV, this change was also observed in the H6, H5 and H9 HA subtypes (Gambaryan et al., 2008). In an analysis of the avidity of the equine and canine IAVs for binding 3' sialylactosamine (3'SLN), Sialyl Lewis X $\left(\mathrm{SLe}^{\mathrm{X}}\right)$, sulphated Sialyl Lewis X (Su-SLe ${ }^{\mathrm{X}}$ ) and Su-3'SLN, the results indicated that the canine virus bound $3^{\prime}$ SLN and SLe ${ }^{\mathrm{x}}$ with an avidity very similar to that of the equine virus, and bound Su-SLe ${ }^{\mathrm{x}}$ and $\mathrm{Su}-$ 3 $^{\text {'SLN }}$ with an avidity approximately one-third to one-half the avidity of the equine virus, which may be linked to the Trp-222 to Leu substitution. Similar differences in receptor binding properties were also observed for the $\mathrm{H} 3 \mathrm{~N} 2$ virus. In a recent study, the reassortant H3N2 viruses rH3N2-222Leu (canine-like) and rH3N2-222Trp (avian-like) with the HA 222-Trp to Leu mutation were generated by reverse genetics (Yang et al., 2013). Compared with rH3N2-222Trp, rH3N2-222Leu grew more rapidly in Madin-Darby Canine Kidney (MDCK) cells and had higher infectivity in primary canine tracheal epithelial cells; in addition, rH3N2-222Leu had a preference for canine tracheal tissues as opposed to avian tissues. All these data suggest that 
this amino acid substitution may facilitate IAV infection in dogs. In canine H3N8 viruses, another noticeable mutation is Thr to Ser at position 30, which influences interactions between $\mathrm{N}$-terminal and $\mathrm{C}$-terminal regions of the subdomain that are important in the structural changes required for membrane fusion activity (Collins et al., 2014). The structural modification may have facilitated the transmission of $\mathrm{H} 3 \mathrm{~N} 8$ virus from horses to dogs.

\section{Prevention of canine influenza}

Vaccination is the primary approach for the control of canine influenza. At present, some progress has been made on CIV vaccines. The CIV H3N8 discovered in 2004 is closely related to H3N8 EIV, and Karaca et al. (2007) have indicated that a canarypox-vectored vaccine expressing the HA gene of H3N8 EIV could induce an antibody response against CIV in dogs. Rosas et al. (2008) reported that a RacH-based vaccine expressing the H3 of EIV subtype H3N8 (RHEIV) was able to induce a robust immune response in dogs and relieve the clinical signs of influenza. Vaccination with these vaccines efficiently decreased morbidity and reduced lung lesions in the affected dogs (Deshpande et al., 2009; Larson et al., 2011). Lee et al. (2010) investigated the efficacy and immunogenicity of a formalin-inactivated avian-origin CIV vaccine. Notably, although the antibody level to CIV H3N2 was significantly elevated, antibodies against swine-origin CIV H3N2 were absent, indicating that the antigenicity of CIV $\mathrm{H} 3 \mathrm{~N} 2$ was different from influenza viruses originating in other species, even though these strains were of the same subtype.

However, influenza vaccines may not be effective enough to prevent infection with divergent viral strains, or may be less immunogenic and effective in certain groups, such as the very young, the old, and the immunocompromised. Many studies have demonstrated that $\mathrm{mAbs}$ are an effective preventive treatment against human-origin (Payungporn et al., 2008) or avian-origin influenza virus infection (Fouchier et al., 2005). To date, only one neutralising mAb specific to the HA2 glycopeptide has been available to prevent and control CIV H3N2 infection (Xie et al., 2015).

Although vaccination is regarded as one of the most effective methods for the prevention of influenza, due to the high evolutionary rate of influenza virus, vaccinated animals sometimes do not generate effective resistance against viruses with novel mutations. Therefore, it is essential to establish new technologies for vaccine development and to shorten the development cycle of vaccines in order to strengthen the prevention and control of influenza virus infection. 


\section{Conclusions}

In recent years, cases of dogs infected by IAVs, including the H3N8 and H2N8 subtypes, have been reported continuously. Although there have been no reports of human infections with $\mathrm{H} 3 \mathrm{~N} 8$ or $\mathrm{H} 3 \mathrm{~N} 2 \mathrm{CIV}$, these viruses may pose tremendous risks to human health. In addition, because various subtypes of influenza viruses can infect dogs, when dogs are infected with two or more subtypes of viruses simultaneously, a novel reassortant virus that can infect humans may be generated. Therefore, it is important to develop better surveillance and control strategies for emerging influenza diseases in dogs.

In addition to the factors discussed above, some key problems remain to be solved. For instance, what led to the interspecies transmission of influenza virus? What is the molecular mechanism of influenza virus infection in dogs? Why can influenza virus continuously be transmitted between dogs? Under what circumstances can CIV infect humans? Only by solving these problems completely can we effectively prevent and control influenza epidemics.

\section{Acknowledgements}

This work was supported by the International S\&T Cooperation Program of China (ISTCP 2014DFG32770), the Graduate Research and Innovation Program of Jiangsu Province (KYLX15_0561), China Scholarship Council and the Priority Academic Program Development of Jiangsu Higher Education Institutions (PAPD).

\section{References}

Anderson, T. C., Bromfield, C. R., Crawford, P. C., Dodds, W. J., Gibbs, E. P. and Hernandez, J. A. (2012): Serological evidence of H3N8 canine influenza-like virus circulation in USA dogs prior to 2004. Vet. J. 191, 312-316.

Bao, Y., Bolotov, P., Dernovoy, D., Kiryutin, B., Zaslavsky, L., Tatusova, T., Ostell, J. and Lipman, D. (2008): The influenza virus resource at the National Center for Biotechnology Information. J. Virol. 82, 596-601.

Bunpapong, N., Nonthabenjawan, N., Chaiwong, S., Tangwangvivat, R., Boonyapisitsopa, S., Jairak, W., Tuanudom, R., Prakairungnamthip, D., Suradhat, S., Thanawongnuwech, R. and Amonsin, A. (2014): Genetic characterization of canine influenza A virus (H3N2) in Thailand. Virus Genes 48, 56-63.

Butler, D. (2006): Thai dogs carry bird-flu virus, but will they spread it? Nature 439, 773.

Castleman, W. L., Powe, J. R., Crawford, P. C., Gibbs, E. P., Dubovi, E. J., Donis, R. O. and Hanshaw, D. (2010): Canine H3N8 influenza virus infection in dogs and mice. Vet. Pathol. 47, 507-517.

Chen, Y., Zhong, G., Wang, G., Deng, G., Li, Y., Shi, J., Zhang, Z., Guan, Y., Jiang, Y., Bu, Z., Kawaoka, Y. and Chen, H. (2010): Dogs are highly susceptible to H5N1 avian influenza virus. Virology 405, 15-19. 
Collins, P. J., Vachieri, S. G., Haire, L. F., Ogrodowicz, R. W., Martin, S. R., Walker, P. A., Xiong, X., Gamblin, S. J. and Skehel, J. J. (2014): Recent evolution of equine influenza and the origin of canine influenza. PNAS 111, 11175-11180.

Crawford, P. C., Dubovi, E. J., Castleman, W. L., Stephenson, I., Gibbs, E. P., Chen, L., Smith, C., Hill, R. C., Ferro, P., Pompey, J., Bright, R. A., Medina, M. J., Johnson, C. M., Olsen, C. W., Cox, N. J., Klimov, A. I., Katz, J. M. and Donis, R. O. (2005): Transmission of equine influenza virus to dogs. Science 310, 482-485.

Daly, J. M., Blunden, A. S., Macrae, S., Miller, J., Bowman, S. J., Kolodziejek, J., Nowotny, N. and Smith, K. C. (2008): Transmission of equine influenza virus to English foxhounds. Emerg. Infect. Dis. 14, 461-464.

Deshpande, M. S., Jirjis, F. F., Tubbs, A. L., Jayappa, H., Sweeney, D., Spencer, S. J., Lakshmanan, N. and Wasmoen, T. L. (2009): Evaluation of the efficacy of a canine influenza virus (H3N8) vaccine in dogs following experimental challenge. Vet. Ther. 10, 103-112.

Dubovi, E. J. (2010) Canine influenza. Vet. Clin. North Am. Small Anim. Pract. 40, 1063-1071.

Dundon, W. G., De Benedictis, P., Viale, E. and Capua, I. (2010): Serologic evidence of pandemic (H1N1) 2009 infection in dogs, Italy. Emerg. Infect. Dis. 16, 2019-2021.

Feng, H. X., Liu, Y. Y., Song, Q. Q., Ling, Z. S., Zhang, F. X., Zhu, Y. L., Jiang, S. J. and Xie, Z. J. (2014): Interspecies transmission of canine influenza virus H5N2 to cats and chickens by close contact with experimentally infected dogs. Vet. Microbiol. 170, 414-417.

Fouchier, R. A., Munster, V., Wallensten, A., Bestebroer, T. M., Herfst, S., Smith, D., Rimmelzwan, G. F., Olsen, B. and Osterhaus, A. D. (2005): Characterization of a novel influenza A virus hemagglutinin subtype (H16) obtained from black-headed gulls. J. Virol. 79, 2814-2822.

Gambaryan, A. S., Tuzikov, A. B., Pazynina, G. V., Desheva, J. A., Bovin, N. V., Matrosovich, M. N. and Klimov, A. I. (2008): 6-sulfo sialyl Lewis X is the common receptor determinant recognized by H5, H6, H7 and $\mathrm{H} 9$ influenza viruses of terrestrial poultry. Virol. J. 5, 85.

Gibbs, E. P. and Anderson, T. C. (2010): Equine and canine influenza: a review of current events. Anim. Health Res. Rev. 11, 43-51.

Giese, M., Harder, T. C., Teifke, J. P., Klopfleisch, R., Breithaupt, A., Mettenleiter, T. C. and Vahlenkamp, T. W. (2008): Experimental infection and natural contact exposure of dogs with avian influenza virus (H5N1). Emerg. Infect. Dis. 14, 308-310.

Han, J. Y., Park, S. J., Kim, H. K., Rho, S., Nguyen, G. V., Song, D., Kang, B. K., Moon, H. J., Yeom, M. J. and Park, B. K. (2012): Identification of reassortant pandemic H1N1 influenza virus in Korean pigs. J. Microbiol. Biotechnol. 22, 699-707.

Jeoung, H. Y., Lim, S. I., Shin, B. H., Lim, J. A., Song, J. Y., Song, D. S., Kang, B. K., Moon, H. J. and An, D. J. (2013): A novel canine influenza H3N2 virus isolated from cats in an animal shelter. Vet. Microbiol. 165, 281-286.

Jung, K., Lee, C. S., Kang, B. K., Park, B. K., Oh, J. S. and Song, D. S. (2010): Pathology in dogs with experimental canine H3N2 influenza virus infection. Res. Vet. Sci. 88, 523-527.

Karaca, K., Dubovi, E. J., Siger, L., Robles, A., Audonnet, J. C., Jiansheng, Y., Nordgren, R. and Minke, J. M. (2007): Evaluation of the ability of canarypox-vectored equine influenza virus vaccines to induce humoral immune responses against canine influenza viruses in dogs. Am. J. Vet. Res. 68, 208-212.

Kirkland, P. D., Finlaison, D. S., Crispe, E. and Hurt, A. C. (2010): Influenza virus transmission from horses to dogs, Australia. Emerg. Infect. Dis. 16, 699-702.

Larson, L. J., Henningson, J., Sharp, P., Thiel, B., Deshpande, M. S., Davis, T., Jayappa, H., Wasmoen, T., Lakshmanan, N. and Schultz, R. D. (2011): Efficacy of the canine influenza virus H3N8 vaccine to decrease severity of clinical disease after cochallenge with canine influenza virus and Streptococcus equi subsp. zooepidemicus. Clin. Vaccine Immunol. 18, $559-564$.

Lee, C., Jung, K., Oh, J., Oh, T., Han, S., Hwang, J., Yeom, M., Son, D., Kim, J., Park, B., Moon, H., Song, D. and Kang, B. (2010): Protective efficacy and immunogenicity of an inacti- 
vated avian-origin $\mathrm{H} 3 \mathrm{~N} 2$ canine influenza vaccine in dogs challenged with the virulent virus. Vet. Microbiol. 143, 184-188.

Lee, J. H., Pascua, P. N., Song, M. S., Baek, Y. H., Kim, C. J., Choi, H. W., Sung, M. H., Webby, R. J., Webster, R. G., Poo, H. and Choi, Y. K. (2009): Isolation and genetic characterization of H5N2 influenza viruses from pigs in Korea. J. Virol. 83, 4205-4215.

Lee, Y. N., Lee, D. H., Lee, H. J., Park, J. K., Yuk, S. S., Sung, H. J., Park, H. M., Lee, J. B., Park, S. Y., Choi, I. S. and Song, C. S. (2012): Serologic evidence of H3N2 canine influenza virus infection before 2007. Vet. Rec. 171, 477.

Li, S. J., Shi, Z. H., Jiao, P. R., Zhang, G. H., Zhong, Z. W., Tian, W. R., Long, L. P., Cai, Z. P., Zhu, X. Q., Liao, M. and Wan, X. F. (2010): Avian-origin H3N2 canine influenza A viruses in Southern China. Infect. Genet. Evol. 10, 1286-1288.

Lin, D., Sun, S., Du, L., Ma, J., Fan, L., Pu, J., Sun, Y., Zhao, J., Sun, H. and Liu, J. (2012a): Natural and experimental infection of dogs with pandemic H1N1/2009 influenza virus. J. Gen. Virol. 93, 119-123.

Lin, Y., Zhao, Y. B., Zeng, X. J., Lu, C. P. and Liu, Y. J. (2012b): Genetic and pathobiologic characterization of H3N2 canine influenza viruses isolated in the Jiangsu Province of China in 2009-2010. Vet. Microbiol. 158, 247-258.

Lipatov, A. S., Govorkova, E. A., Webby, R. J., Ozaki, H., Peiris, M., Guan, Y., Poon, L. and Webster, R. G. (2004): Influenza: emergence and control. J. Virol. 78, 8951-8959.

Lyoo, K. S., Kim, J. K., Kang, B., Moon, H., Kim, J., Song, M., Park, B., Kim, S. H., Webster, R. G. and Song, D. (2015): Comparative analysis of virulence of a novel, avian-origin H3N2 canine influenza virus in various host species. Virus Res. 195, 135-140.

Maas, R., Tacken, M., Ruuls, L., Koch, G., van Rooij, E. and Stockhofe-Zurwieden, N. (2007): Avian influenza (H5N1) susceptibility and receptors in dogs. Emerg. Infect. Dis. 13, 1219-1221.

Muranaka, M., Yamanaka, T., Katayama, Y., Niwa, H., Oku, K., Matsumura, T. and Oyamada, T. (2012): Time-related pathological changes in horses experimentally inoculated with equine influenza virus. J. Equine Sci. 23, 17-26.

Neumann, G., Noda, T. and Kawaoka, Y. (2009): Emergence and pandemic potential of swineorigin H1N1 influenza virus. Nature 459, 931-939.

Newton, J. R., Daly, J. M., Spencer, L. and Mumford, J. A. (2006): Description of the outbreak of equine influenza (H3N8) in the United Kingdom in 2003, during which recently vaccinated horses in Newmarket developed respiratory disease. Vet. Rec. 158, 185-192.

Parrish, C. R., Murcia, P. R. and Holmes, E. C. (2015): Influenza virus reservoirs and intermediate hosts: dogs, horses, and new possibilities for influenza virus exposure of humans. J. Virol. 89, 2990-2994.

Payungporn, S., Crawford, P. C., Kouo, T. S., Chen, L. M., Pompey, J., Castleman, W. L., Dubovi, E. J., Katz, J. M. and Donis, R. O. (2008): Influenza A virus (H3N8) in dogs with respiratory disease, Florida. Emerg. Infect. Dis. 14, 902-908.

Pecoraro, H. L., Spindel, M. E., Bennett, S., Lunn, K. F. and Landolt, G. A. (2013): Evaluation of virus isolation, one-step real-time reverse transcription polymerase chain reaction assay, and two rapid influenza diagnostic tests for detecting canine Influenza A virus H3N8 shedding in dogs. J. Vet. Diagn. Invest. 25, 402-406.

Piccirillo, A., Pasotto, D., Martin, A. M. and Cordioli, P. (2010): Serological survey for influenza type A viruses in domestic dogs (Canis lupus familiaris) and cats (Felis catus) in northeastern Italy. Zoonoses Public Health 57, 239-243.

Rivailler, P., Perry, I. A., Jang, Y., Davis, C. T., Chen, L. M., Dubovi, E. J. and Donis, R. O. (2010): Evolution of canine and equine influenza (H3N8) viruses co-circulating between 2005 and 2008. Virology 408, 71-79.

Romváry, J. and Tanyi, J. (1975): Occurrence of Hong Kong influenza A (H3N2) virus infection in the Budapest Zoo. Acta Vet. Acad. Sci. Hung. 25, 251-254. 
Romváry, J., Rózsa, J. and Farkas, E. (1975): Infection of dogs and cats with the Hong Kong influenza A (H3N2) virus during an epidemic period in Hungary. Acta Vet. Acad. Sci. Hung. 25, 255-259.

Rosas, C., Van de Walle, G. R., Metzger, S. M., Hoelzer, K., Dubovi, E. J., Kim, S. G., Parrish, C. R. and Osterrieder, N. (2008): Evaluation of a vectored equine herpesvirus type 1 (EHV-1) vaccine expressing $\mathrm{H} 3$ haemagglutinin in the protection of dogs against canine influenza. Vaccine 26, 2335-2343.

Schulz, B., Klinkenberg, C., Fux, R., Anderson, T., de Benedictis, P. and Hartmann, K. (2014): Prevalence of canine influenza virus A (H3N8) in dogs in Germany. Vet. J. 202, 184-185.

Song, D., Kang, B., Lee, C., Jung, K., Ha, G., Kang, D., Park, S., Park, B. and Oh, J. (2008): Transmission of avian influenza virus (H3N2) to dogs. Emerg. Infect. Dis. 14, 741-746.

Song, D., Moon, H. J., An, D. J., Jeoung, H. Y., Kim, H., Yeom, M. J., Hong, M., Nam, J. H., Park, S. J., Park, B. K., Oh, J. S., Song, M., Webster, R. G., Kim, J. K. and Kang, B. K. (2012): A novel reassortant canine H3N1 influenza virus between pandemic H1N1 and canine H3N2 influenza viruses in Korea. J. Gen. Virol. 93, 551-554.

Song, D. S., An, D. J., Moon, H. J., Yeom, M. J., Jeong, H. Y., Jeong, W. S., Park, S. J., Kim, H. K., Han, S. Y., Oh, J. S., Park, B. K., Kim, J. K., Poo, H., Webster, R. G., Jung, K. and Kang, B. K. (2011): Interspecies transmission of the canine influenza H3N2 virus to domestic cats in South Korea 2010. J. Gen. Virol. 92, 2350-2355.

Song, Q. Q., Zhang, F. X., Liu, J. J., Ling, Z. S., Zhu, Y. L., Jiang, S. J. and Xie, Z. J. (2013): Dog to dog transmission of a novel influenza virus (H5N2) isolated from a canine. Vet. Microbiol. 161, 331-333.

Songserm, T., Amonsin, A., Jam-on, R., Sae-Heng, N., Pariyothorn, N., Payungporn, S., Theamboonlers, A., Chutinimitkul, S., Thanawongnuwech, R. and Poovorawan, Y. (2006): Fatal avian influenza A H5N1 in a dog. Emerg. Infect. Dis. 12, 1744-1747.

Sponseller, B. A., Strait, E., Jergens, A., Trujillo, J., Harmon, K., Koster, L., Jenkins-Moore, M., Killian, M., Swenson, S., Bender, H., Waller, K., Miles, K., Pearce, T., Yoon, K. J. and Nara, P. (2010): Influenza A pandemic (H1N1) 2009 virus infection in domestic cat. Emerg. Infect. Dis. 16, 534-537.

Sun, Y. P., Shen, Y., Zhang, X. X., Wang, Q., Liu, L. Q., Han, X., Jiang, B., Wang, R., Sun, H. L., Pu, J., Lin, D. G., Xia, Z. F. and Liu, J. H. (2014): A serological survey of canine H3N2, pandemic H1N1/09 and human seasonal H3N2 influenza viruses in dogs in China. Vet. Microbiol. 168, 193-196.

Sun, Y. P., Sun, S. S., Ma, J. J., Tan, Y. Y., Du, L. J., Shen, Y., Mu, Q. H., Pu, J., Lin, D. G. and Liu, J. H. (2013): Identification and characterization of avian-origin H3N2 canine influenza viruses in northern China during 2009-2010. Virology 435, 301-307.

Teng, Q. Y., Zhang, X., Xu, D. W., Zhou, J. W., Dai, X. G., Chen, Z. G. and Li, Z. J. (2013): Characterization of an $\mathrm{H} 3 \mathrm{~N} 2$ canine influenza virus isolated from Tibetan mastiffs in China. Vet. Microbiol. 162, 345-352.

Tong, S., Li, Y., Rivailler, P., Conrardy, C., Castillo, D. A., Chen, L. M., Recuenco, S., Ellison, J. A., Davis, C. T., York, I. A., Turmelle, A. S., Moran, D., Rogers, S., Shi, M., Tao, Y., Weil, M. R., Tang, K., Rowe, L. A., Sammons, S., Xu, X., Frace, M., Lindblade, K. A., Cox, N. J., Anderson, L. J., Rupprecht, C. E. and Donis, R. O. (2012): A distinct lineage of influenza A virus from bats. PNAS 109, 4269-4274.

Xie, X., Lin, Y., Pang, M. D., Zhao, Y. B., Kalhoro, D. H., Lu, C. P. and Liu, Y. J. (2015): Monoclonal antibody specific to HA2 glycopeptide protects mice from $\mathrm{H} 3 \mathrm{~N} 2$ influenza virus infection. Vet. Res. 46, 33.

Yang, G., Li, S., Blackmon, S., Ye, J., Bradley, K. C., Cooley, J., Smith, D., Hanson, L., Cardona, C., Steinhauer, D. A., Webby, R., Liao, M. and Wan, X. F. (2013): Mutation tryptophan to leucine at position 222 of haemagglutinin could facilitate H3N2 influenza A virus infection in dogs. J. Gen. Virol. 94, 2599-2608. 
Zeng, X. J., Lin, Y., Zhao, Y. B., Lu, C. P. and Liu, Y. J. (2013): Experimental infection of dogs with H3N2 canine influenza virus from China. Epidemiol. Infect. 141, 2595-2603.

Zhan, G. J., Ling, Z. S., Zhu, Y. L., Jiang, S. J. and Xie, Z. J. (2012): Genetic characterization of a novel influenza A virus H5N2 isolated from a dog in China. Vet. Microbiol. 155, 409-416. 